\title{
Comparative Study of the Professional Development of Special Physical Education between China and America
}

\author{
Xiaoqin Guo ${ }^{1}$ \\ ${ }^{1}$ Department of Physical Education in Nanchang Teachers College, Nanchang, Jiangxi, China
}

Keywords: America; China; special sport; adapted physical education; disabilities; vulnerable groups.

\begin{abstract}
Through comparative study of special sports professional development between China and America, this paper found that there are large differences in its history background, and education regulations protection, and training mode, and education assessment system, which summed up the insufficient of special sports professional development and needs to be solved in China, then, made corresponding development countermeasures on this basis, in order to promote the sustainable development of Chinese special sports professional.
\end{abstract}

\section{Preface}

Education for special populations is the necessary conditions to adhere to the people-oriented, develop fair education and construct harmonious society.Achieving balanced development of education over the years is the direction of Chinese education efforts. By the joint efforts of all sectors of society, the tasks index of Chinese Disabled Persons' Cause of the Eleventh Five-Year Development Program has been fully completed,on this basis, in order to accelerate promoting the construction of the social security system and the service system for persons with disabilities, Chinese government have drawn up Chinese Disabled Persons' Cause of the Twelfth Five-Year Development Program, which raises that it will continues to perfect the disability children juvenile compulsory education system that regards special education school as backbone,and regards study with class and special education as the main part, moreover, accelerate the popularization and improve school-age disability compulsory education level of children and adolescents. This shows that China attaches great importance to the education for disability groups, which provides policy support for the cause of the rapid development of special physical education.

Special physical education professional development in United States for nearly half a century of historical background,a special physical talent training system has been established from undergraduate to doctoral students' stage,with extensive talent training experience. By contrast, there is only 15 years of special physical education history in China,although it has achieved some results, it is still at the exploratory stage, there are significant limitations both in the segment of theory and practice. On the base of grasping a large number of reference materials at home and abroad, this article attempted to find out domestic shortcomings and problems to be solved in view of the systemic comparative study of the historical background of the development about the special physical education between China and America, and education regulations protection, and training mode, and the system of education assessment, then, made relevant recommendations to promote the professional development of Chinese special physical education.

\section{Comparisons of the Historical Background of Development}

Chinese Developmental History of Special Physical Education. Special education in China started relatively late, in the mid 1990 of the 20th century, the establishment of special education subject in East China Normal University indicates that Chinese special education enterprise has entered a new stage, however, the major of special physical education was set up firstly by Tianjin Institute of physical education, so as to make up for a vacancy on the cultivation of the special physical education teachers in China. Cultivation of special physical education teachers truly means the beginning of special physical education in China. At present, there are extremely lack of 
specialized physical education teachers, the university that has opened special physical education major are only Tianjin Institute of Physical Education, Shanghai Institute of Physical Education, Xi'an Institute of Physical Education, Shandong Institute of Physical Education, Liaoning Normal University, and Guangzhou Institute of Physical Education, special physical education in China starting late and radiating narrowly is still a notable phenomenon as a whole. At present, the development of china special physical education is in its infancy, he training system still need to be gradually improved.

Historical Background of the Development of the Special Physical Education in the United States. The training of special physical education teacher in the United States has a long history. It was a starting point for the cultivation of special physical education teachers to the United States in1967, the development speed of its major is very fast. After 45 years, the United States has established fairly complete training system for the special physical talents, from the undergraduate to the doctoral phase, the setting of the major is very rich, and the training structure is fairly integrated. Moreover, the cultivation of special physical talent is closely related to the educational form of children with disabilities the nation set in America, for the sake of actually serving special populations, and meet the demands of society, this is the root why special physical education in a high degree of sustainable development. Therefore, half a century of special physical education professional training experience in the United States is well worth our reference.

\section{Comparison of the Legal Guarantee of Special Education}

The Background of Chinese Special Education Legislation. Since the beginning of reform and opening up, China has successively enacted the Education Act, the Compulsory Education Act, the Protection of Disabled Persons Act, the Education Ordinance for Persons with Disabilities, the Detailed Rules for the Implementation of Compulsory Education, Special Education Schools Provisional Regulations and so on, and permitted to join the United Nations Convention on the Rights of Persons with Disabilities, this provides legal protection for the development of education for persons with disabilities in China and safeguarding the rights of the disabled, especially children with disabilities to the education.

The Background of American Special Education Legislation. A high degree of development of special education in America benefits from the formulation of the relevant education regulations. In order to protect persons with disabilities have the education, as well as respect for human rights of persons with disabilities, the United States not hesitate to judicial intervention. American Education for the Handicapped Act clearly stipulated that adapted physical education is part of the special education. 90-170 Public Law in the United States formally implemented in 1967, fifth paragraph of it clearly stated providing funding for special physical education teacher' training and research. In addition, there are some federal legislation associated with the adapted physical education, such as Rehabilitation (PL93-112),1973, Children with Disabilities Education Act (PL94-142), 1975, PL95-606 of Amateur Sports Act, 1978, American Disability Act(PL101-336), 1990, deactivation of individual education law (PL101-476), 1990. There are such sound special education legislations to protect the sustained and healthy development of special education in the United States.

\section{Comparison of the Model of Special Physical Education Teachers' Training}

The Objectives of the Training. The objectives of the special physical education training is mainly reflected in two aspects, one objective is to cultivate the diversified basic theoretical knowledge of the special education and practical ability, another objective is to improve professionalism. The objectives of the training achieve through the basic course, courses and specialized elective courses to enrich the students' knowledge, meanwhile, broaden the horizons of the students' knowledge, to lay a solid foundation for subsequent learning of the expertise of the special physical education. The expertise of the special physical education focuses on assessment, diagnosis and evaluation of students with disabilities, according to the different needs of students 
with disabilities, the teachers creatively design and arrange teaching, and flexible to address practical difficulties that may be encountered in the process of teaching.

Personnel training objectives of the institutes of physical education which have set up special physical education major are basically identical, all of them have put forward overall requirements to the qualities and specifications of the people they want to cultivate. The specific aim is to nurture complex talent that master the knowledge and skills of teaching, training, competition, management, rehabilitation, and research for disabled sports, convey applicative talents to the sectors such as special schools, primary and secondary schools, rehabilitation institutions, communities, and the disabled sports organizations for the disabled.

Training Form and Educational System. In the United States, there are characteristics of regional autonomy in higher education, the states arrange special physical education teacher training form and educational system according to their own autonomous system. For example, training form in Ohio State University caters to the students majoring in Physical Education to open the courses of special physical education, however, students get the certificate of special physical education teacher only if they first obtain a K-12-year-old physical education certificate. Eastern Oregon University takes all students majoring in physical education as the training base of special physical education teachers. In terms of training system, there are mainly four-year professional training and 3+1 type(a mixed education mode with studying physical education three years plus studying special physical education one year). The flexible training form and educational system in America can better adapt to the actual demand. In China, at this stage special physical education teacher training is mainly borne by a handful of institutes of physical education, schooling is 4 years, there are two main forms of training, one form is the establishment of special physical education to train teachers, another form is cultivate physical education teachers on the basis of physical education major. In contrast, the training form of special physical education teachers is relatively single, it should develop towards the direction of diversification to broaden the way of training.

Curriculum. The standard of special physical educational curriculum is an important basis for the implementation of special physical education and curriculum. In 1991, for the sake of speeding up the development of special physical education, the United States Federation of the disabled and leisure put forward a five-year (1992-1997) program about the national adapted physical education curriculum standards and the establishment of professional license verification to the United States Department of Education, Special Education and Rehabilitation Services, and the Personnel Reserve, then, enacted and carried out $\mathrm{f}$ a essential file--the national standards for the adapted physical education curriculum. The national standards of American curriculum provides an important basis for the special physical education curriculum setting, its core content stipulated by the 15 professional standards of special physical education curriculum and knowledge requirements its main objectives set. In the curriculum, the professional theory of the special physical education combines with practice closely, including three core components of the basic courses, professional courses and practical courses. The basic course covers a wide range of knowledge, it contains both the social sciences and natural sciences, sports science accounts for a large proportion, such as exercise physiology, sport and health science, sports training, sports psychology. Professional courses include two blocks of general theory of disabled persons and persons with disabilities in the professional theory of physical education, the curriculum the latter involving includes an introduction to physical education, special physical education method for persons with disabilities, athletic evaluation of special children, the history and law of the special physical education. Practice course is also an important part of professional courses of special physical education in America, Practicum Experience Provided is opened exclusively for the cultivation of practice ability of the students. Practical courses enable the students to learn and master the knowledge of special physical education in the process of practice, apply theory to practice, sum up experience from the practice and learn lessons.

The curriculum is the core of the professional construction which determines the quality of the personnel training. The special physical education is a cross-disciplinary and requires a high degree of integration in the professional curriculum. At present, integration of the courses of special physical 
education in various sports institutions in China is not enough, curriculum simply sums up with the pedagogy, physical training and rehabilitation medicine class. I believe that the nature of the special physical education of professional courses should highlight the word "special", should address the future employment of the students(set up physical education courses adapting to the persons with disabilities for persons with disabilities, rather than the physical education curriculum-based, supplemented by special physical education. Highlighting the "special physical" as the core curriculum is a key link in developing special talents in sports that meet social need, therefore, we should try to overcome the restrictions (e.g., teachers' professionalism , special physical education facilities and equipment conditions), increase the proportion of disabled sports courses, design a more rational system of special physical education course.

\section{Comparison of Special Physical Education Assessment System}

In 1973, the United States published a training guide of special physical education teachers, at the mid-1980s, the U.S. Department of Education called for a standard of the training of special physical education teacher in order to assess the quality of the training of special physical education teacher. To this end, in 1984, Oakley introduced the undergraduate special sports teacher evaluation guide. In addition, the identification of the quality of teacher training also depends on the implementation of the system of professional certificates. In United States, the teachers engaging in special education get general school teachers qualification certificate, also get special school teachers qualification certificate at the same time, they obtain professional certificate in corresponding area according to the specific disability situation of object, and only through this series of qualifications examination in order to achieve full certification of special education teachers, and the timeliness of the certificate is usually valid for five years, it need to be recognized again after five years. It is thus clear that the assessment of the quality of special education system has been relatively well in America. In China, the training of the special physical education teacher has been the lack of authority of the training guidelines and quality assessment criteria, special physical education teachers' accreditation system has not yet been established, there are short of detailed provisions about the special expertise which special physical education teachers should have, therefore, special physical education assessment system has yet to be perfected.

\section{Conclusions and Recommendations}

Adding Training Direction of the Special Physical Education. Special education in China developed rapidly with economic development and progress of social civilization, according to the statistical bulletin of the 2010 cause development for persons with disabilities in China, china have set up 1705 special education schools for the children with blind, deaf, mentally retarded, ordinary schools with compulsory education set up 2775 special education classes, there are 519 thousands children with blind, deaf and mentally retarded at the school. China has formed a scholastic mode(in this mode, special education carry on mainly in special education schools, supplement with studying with class in ordinary schools). The development of special education is dependent on a large number of teachers which have special education skills and master special education theory. For physical education, the training of special physical education teachers has become an urgent task. At present, the contradiction of supply and demand between social needs and special physical education teachers to be eased needs to intensify the training of special physical education teachers, according to Chinese current education, creation of special physical education in physical education can be one of the most reasonable ways. The direction of the special physical education enables students to study the physiological and psychological aspects of the disabled on the basis of mastering skills and knowledge in physical education, so, the students can really fit for teaching work of physical education in special schools or the condition of the students with disabilities studying with class in ordinary schools.

Integration of Local Education Resources, Fostering in Various Forms. Teacher training in the form of special sports can be varied.(1) Currently, the main channel of training special sports 
teachers in China is opening of special sports education major in the university, in other words, sports institutions recruit the students studying special physical education, train them professionally according to corresponding training targets, but this training model are vulnerable to the limitations of educational resources, such as the special professional faculty, therefore, to some extent, it affects the quality of personnel training;(2) We should combine with the actual conditions of the universities, fully integrate school-based education resources and establish a joint training model of the physical education major and special education, maximize school-based resources to address the resources of the training of special physical education teacher, including especially the special teacher resources, to effectively improve the quality of special physical education professionals; (3) In-service training. The physical education teachers in primary and secondary schools, or even kindergarten complement the special expertise in the form of continuing education in order to improve the current situation of lack of special physical education teachers in the basic education in China.

Perfect Disabilities Education Regulations. China has developed appropriate regulations to the development of education for persons with disabilities, protects the rights of special populations to receive education, it also promotes the development of special education, but there is still a certain distance comparing with the sound special education regulations in the United States, it mainly reflected in the bill of undisclosed fine, lack of specific guidance, there is a discrepancy between theory and some practice operations. Therefore, I consider that the relevant departments should strengthen the related legislation of the special education, perfect the system of laws, regulations and policies for the cause of the persons with disabilities. So that, there are rules to follow in actual conditions, protect the cultural and educational rights of persons with disabilities.

Set Up and Perfect the Standards of the Teacher Qualification of the Special Physical Education. China started to implement the system of teacher qualification in 2001, established the corresponding standards of the teacher qualification, but there is a "one size fits all" phenomenon in the standards of the teacher qualification at present, special physical education teachers and general teachers held the same certificates, it did not develop special qualification for the standards of special physical education. Special Physical Education is a major requiring a high level of professional expertise, the teachers be trained should have professional education and teaching skills in order to meet society's needs. If using ordinary teacher qualification standards to require physical education teachers in particular will not be conducive to promoting the specialization of the special physical education. Therefore, the standards of the teachers' accreditation of special physical education should be established in China, including the standards of professional access to the teachers, the standards of teachers 'knowledge structure and he standards of teacher's teaching ability. According to the current national conditions of China's education, China may apply the system of "one post with double certificates" , in other words, special physical education teachers while holding ordinary teacher qualification are required to obtain teacher qualification of special physical education before induction.

\section{References}

[1] Xie Tao.Problems and Suggestions for Specialization of Teachers for Special Physical Education in China [J]. Journalof Shanghai University of Sport, 2011,35(4):80.

[2] LI Chun-xiao, WU Yan-dan, WU Li-fang. Instructort Raining of Teachers of Sports for Disabled in China and U.S. [J]. Journal of Wuhan Institute of Physical Education, 2010,5(44):96-99.

[3] Wang Jian-xin, Chen Jie-min. Discussion on the Feasibility of Cultivating Special P.E. Teachers in P.E. Institutions[J]. Journal of Beijing Sport University, 2006,8(29):1116-1118.

[4] Li Qun-li, Luo Zhi-bo. National Standards of Adapted Physical Education in the US and Its Implication to Special Physical Education in China[J]. Chinese Journal of Special Education, 2009,(7):28-31. 
[5] HouXiao-hui, Wan Yu. Present Situation and Strategies of Special Physical Education Major Construction in Higher Institutes of Physical Education[J].Capital Institute of Physical Education, 2010,4(22): :51-54.

[6] Zhao Ha, The Preparation Model of American Special Physica Education Teachers and Its Enlightenment on China[J]. Chinese Journal of Special Education, 2010,10:17-20. 